\title{
Original Article \\ Correlation between Ultrasonographic Placental Maturation Study and Pregnancy Outcome
}

\author{
Authors \\ Dr Lucy Das ${ }^{1}$, Dr Umakant Satapathy ${ }^{2}$, Dr Jasmin Rath ${ }^{3}$ \\ ${ }^{1}$ Professor \& Head, Department of Obstetrics \& Gynaecology, SCB Medical College, Cuttack, Odisha, \\ Email: dr.lucydas@gmail.com Mob No. +919437255580 \\ ${ }^{2}$ Associate Professor Physiology, Joint Director, Medical Education \&Training India, \\ ${ }^{3}$ Consultant, Apollo Hospitals, Apollo Health City Campus, Hyderabad, \\ Email: jasminrath@gmail.com, Mob No.+919392163962 \\ Corresponding Author \\ Dr Umakant Satapathy \\ Associate Professor Physiology, Joint Director, Medical Education \&Training, \\ N-3/462, IRC Village, Nayapalli, Bhubaneswar, Odisha, India 751015 \\ Email: uksatapathy@yahoo.co.uk Mobile Number: 91-9437410842
}

\begin{abstract}
Placenta plays a key role in maintenance of milieu interior in the growing foetus by establishing a vital connection between the mother and foetus. Any change or deterioration in the placental function as seen in placental ageing or placental insufficiency, can indicate the outcome of pregnancy and if detected can help in timely appropriate intervention to save the life of baby as well as mother. Grade III placental changes if found early in pregnancy can indicate increased peri-natal morbidity and mortality more particularly in high risk pregnancies. 150 cases (50 normal and 100 high risk) cases were studied for a correlation between the placental grades and the foetal outcome. It is observed that there is a definite correlation between the grades of placenta and foetal outcome. In our study grade III placenta was seen mostly (35\%) at 32-37weeks of gestation. A definite correlation is found between the advanced maturity of placenta and high risk pregnancies like PIH, Intra uterine growth retardation (IUGR) and sickle cell anaemia but a delayed maturity of placenta is seen in diabetes and Rh-ve pregnancies. Incidence of foetal distress was observed more with grade III placenta (51.4\%) as compared to grade I and II placenta. Birth asphyxia was observed in $28.57 \%$ of high risk cases with grade III placenta. Low birth weight baby was seen in with grade III placenta in $50.25 \%$ cases. The results are consistent with result of other group. Detection of higher grades of placenta early in $3^{\text {rd }}$ trimester can alert the obstetrician for close observation regarding development of PIH, IUGR, foetal distress and foetal maturity as there is definite correlation of early maturation of placenta with foetal complications.
\end{abstract}

Key Words: placental grades, ultrasonography, high risk pregnancy, foetal outcome

\section{Introduction}

Placenta plays a key role in maintenance of milieu interior in the growing foetus by establishing a vital connection between the mother and foetus. As the pregnancy advances maturational changes in the placenta occurs. Any change or deterioration in the 
placental function as in placental ageing or placental insufficiency, can indicate the outcome of pregnancy and if detected can help in timely appropriate intervention to save the life of baby as well as mother. Ultrasound unquestionable a long way in providing information about localisation of placenta and different grades of maturational changes in the placental parenchyma, which is indicative of placental ageing in normal pregnancy and chronic placental insufficiency in cases of high risk pregnancies. The common changes observed are thickening of basal lamina of trophoblast and capillaries, obliteration of foetal vessels, deposition of fibrin on surface of villi, intervillous space and on chorionic plates and calcification or cyst formation. The maturational changes are associated with pulmonary maturity and growth of the foetus The grade I placenta is commonly found at 31 weeks, grade II at 36 weeks and grade III at 38 weeks of gestation. Petrucha RA et al. ${ }^{1}$ found that grade III placenta fully correlates with lung maturity and the child born never had developed respiratory distress syndrome. Breckle $\mathrm{R}$ et al. $^{2}$ and others found similar results and suggested that grade II placenta can replace invasive foetal lung maturity tests around term scheduled for repeat caesarean section. Prediction can be made regarding various maternal and foetal complications like Preeclamptic toxaemia, Intra uterine growth retardation, diabetes, post-datism etc. Kazzi GM et al. ${ }^{3}$ found a major accelerating effect on grade of placenta cases in pregnancy with hypertension which is out of proportion to other parameter like Bi-parietal diameter, $\mathrm{L} / \mathrm{S}$ ratio etc. The present study is aimed at finding such correlations between the ultrasonography finding of placental grading with the pregnancy outcome.

\section{Material \& Methods}

The study was carried out in a tertiary care centre attending the antenatal clinic in the out patients department and booked cases in the labour room in emergency. Total 150 cases were studied out of which 50 cases were normal and 100 cases having medical or obstetric complications were considered as high risk cases. Unbooked cases attending the labour room in emergency were excluded from study. After taking a thorough history, clinical examination were subjected to ultrasonographic evaluation for foeto-placental profile. At least one ultrasonic evaluation was done at 28-32 weeks of gestation or at 36-38 weeks of gestation. Perinatally all the cases were followed to note the labour and foetal outcome. Parameters like birth weight, apgar score, development of respiratory distress syndrome, and peri-natal mortality were recorded and correlated with placental grading. Neonates were followed up to seven days after birth. Statistical analysis was done for all the recorded data.

\section{Results}

The distribution of different high risk and normal cases in different gravida are shown in Table 1. The other correlations are shown from Table 2 to 5 and in figures $1 \& 2$.

Table. No 1 Distribution of high risk and normal cases.

\begin{tabular}{|c|c|c|c|}
\hline $\begin{array}{l}\text { Sl } \\
\text { No }\end{array}$ & Parameters & $\begin{array}{c}\text { Number of } \\
\text { cases }\end{array}$ & Percentage \\
\hline 1 & $\begin{array}{c}\text { Complications of pregnancy } \\
\text { (100) } \\
\text { Pregnancy induced } \\
\text { hypertension } \\
\text { Sickle Cell Anaemia } \\
\text { Ante-partum haemorrhage } \\
\text { Post dated pregnancy } \\
\text { Idiopathic intra uterine growth } \\
\text { retardation } \\
\text { Rh negative pregnancy } \\
\text { Gestational diabetes mellitus }\end{array}$ & $\begin{array}{c}35 \\
\\
20 \\
6 \\
15 \\
15 \\
\\
6 \\
3 \\
\end{array}$ & $\begin{array}{c}35 \% \\
20 \% \\
6 \% \\
15 \% \\
15 \% \\
6 \% \\
3 \% \\
\end{array}$ \\
\hline 2 & $\begin{array}{c}\text { Gravida } \\
\text { G1 } \\
\text { G2 } \\
\text { G3 } \\
\text { G4 and above }\end{array}$ & $\begin{array}{c}48 \\
34 \\
12 \\
6\end{array}$ & $\begin{array}{c}48 \% \\
34 \% \\
12 \% \\
6 \%\end{array}$ \\
\hline 3 & $\begin{array}{c}\text { Distribution of normal cases } \\
\text { (50) } \\
\text { Gravida } \\
\text { G1 } \\
\text { G2 } \\
\text { G3 } \\
\text { G4 and above }\end{array}$ & $\begin{array}{c}28 \\
13 \\
8 \\
1\end{array}$ & $\begin{array}{c}56 \% \\
26 \% \\
16 \% \\
2 \%\end{array}$ \\
\hline
\end{tabular}

The correlation of placental grading with gestational age in different high risk cases is shown in Table No. 2 . 
Table. No 2 Correlation of Placental grading with gestational age in different cases.

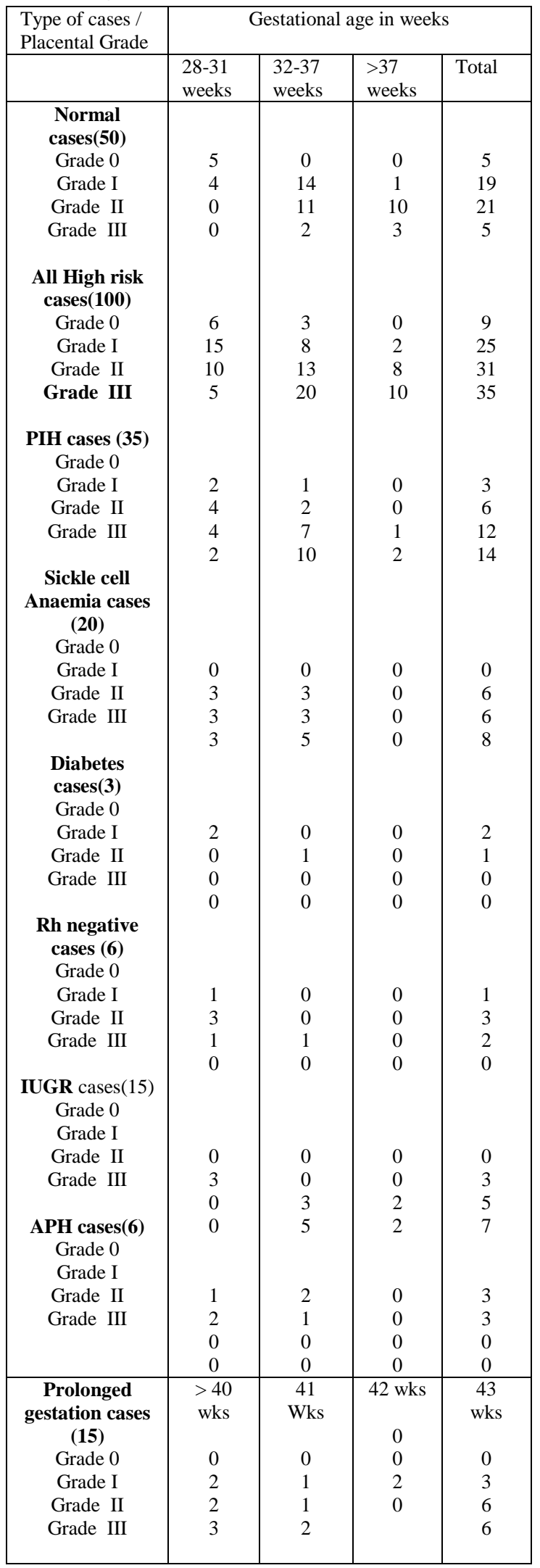

\section{Discussion}

Maturational changes in placenta have been found to correlate with functional maturity of foetus.
Premature ageing of placenta is an indication of decline in its function and is found to be associated with and increased incidence of maternal and foetal complications in form of hypertension, IUGR, foetal demise and peri-natal mortality. Presence of Grade III placenta in early pregnancy requires close monitoring with the continuation of pregnancy. The aim of this study was to correlate the placental maturation in relation to peri-natal outcome in normal and high risk pregnancy. Maximum numbers of high risk cases were found due to Pregnancy Induced Hypertension (PIH) (35\%) followed by sickle cell anaemia (20\%). Hill LM et al. $^{4}$ and Agrawal $\mathrm{V}$ et al. ${ }^{5}$ in their studies found similar incidences. Out of the high risk cases majority were seen in primigravida (48\%). It is observed that in normal cases grade III placenta is seen after 37 weeks of pregnancy where the grade I \& II are mostly seen is seen after 32 weeks. In high risk cases grade II \& III are seen in between 32-37 weeks, grade I is seen at 28-32 weeks of gestation. This result is consistent with findings of Grannum et al. ${ }^{6}$ In our study Grade III placenta is observed in $70.14 \%$ of high risk cases before term. Clair MR et al. ${ }^{7}$ showed that placental grading need to be a part of multifactorial assessment of foetal outcome in high risk pregnancy.

A definite relationship between high risk pregnancy and placental grading is also observed by Agrawal $\mathrm{V}$ et al. ${ }^{5}$ who showed a define advanced maturity of placenta in cases of PIH, Intra uterine growth retardation (IUGR) and sickle cell anaemia but a delayed maturity of placenta in diabetes and $\mathrm{Rh}-\mathrm{ve}$ pregnancies. Arias $\mathrm{F}$ et $\mathrm{al}^{8}$ found advanced grade of placenta in sickle cell anaemia. In the present study it is seen that in PIH cases the appearance of grade III placenta is seen at 32 weeks but a lag in high placental grade in diabetes cases. Six numbers of $\mathrm{Rh}$ -ve cases did not show grade III placenta indicating a delayed maturity of placenta. In our study grade III placenta was shown to be associated with prolonged pregnancy consistent with similar results by Arias $\mathrm{F}$ et $\mathrm{al}^{8}$. In IUGR cases there is observation of more grade III placenta at 32 weeks of gestation. Kazzi GM et al. ${ }^{9}$ have demonstrated that grade III 


\section{JMSCR Vol||05||Issue||04||Page 20516-20521||April}

placenta is significantly related to delivery of Small for gestational age (SGA) ( $<34$ weeks) with a true positive rate of $62 \%$ and sensitivity of $66 \%$ ( $\mathrm{p}<0.008)$. Incidence of foetal distress was observed more with grade III placenta $(51.4 \%)$ observed at 32 weeks as compared to grade I and II placenta. Birth asphyxia was observed in $28.57 \%$ of high risk cases in grade III placenta seen mostly at 32 weeks and $12.9 \%$ in grade II placenta compared to $25 \%$ of asphyxia shown by others. The Apgar Score provides valuable information about the overall health of new born.

Table No. 3 Correlation between placental grading and foetal distress, birth asphyxia and peri natal morbidity.

\begin{tabular}{|c|c|c|c|c|c|c|c|c|c|c|c|c|}
\hline & \multicolumn{3}{|c|}{ Grade 0} & \multicolumn{3}{|c|}{ Grade I } & \multicolumn{3}{|c|}{ Grade II } & \multicolumn{3}{|c|}{ Grade III } \\
\hline & Tot & No & $\%$ & Tot & No & $\%$ & Tot & No & $\%$ & Tot & No & $\%$ \\
\hline $\begin{array}{c}\text { Foetal Distress } \\
\text { Normal Cases (50) }\end{array}$ & 5 & 0 & 0 & 19 & 1 & 5.26 & 21 & 2 & 9.52 & 5 & 1 & 20 \\
\hline High Risk Cases (100) & 9 & 0 & 0 & 25 & 2 & 8 & 31 & 4 & 12.9 & 35 & 18 & 51.42 \\
\hline $\begin{array}{c}\text { Birth Asphyxia } \\
\text { Normal Cases }(50)\end{array}$ & 5 & 0 & 0 & 19 & 1 & 526 & 21 & 2 & 952 & 5 & 0 & 0 \\
\hline High Risk Cases (100) & 9 & 0 & 0 & 25 & 2 & 8 & 31 & 4 & 12.9 & 35 & 10 & 28.57 \\
\hline Perinatal Morbidity & 5 & 0 & 0 & 19 & 1 & 5.2 & 21 & 2 & 9.5 & 5 & 0 & 0 \\
\hline $\begin{array}{c}\text { Normal Cases (50) } \\
\text { High Risk Cases (100) }\end{array}$ & 9 & 3 & 33.3 & 25 & 4 & 16 & 31 & 5 & 6.1 & 35 & 10 & 28.57 \\
\hline
\end{tabular}

Table No. 4 Correlation of placental grading and foetal growth

\begin{tabular}{|c|c|c|c|c|c|c|c|c|c|c|c|c|c|c|c|c|}
\hline Cases & & Srac & & & & Grade & & & & Grad & & & & $\mathrm{rads}$ & & \\
\hline & Total & $\begin{array}{l}\text { A } \\
\text { G } \\
\text { A }\end{array}$ & $\begin{array}{l}\text { IU } \\
\text { GR }\end{array}$ & $\begin{array}{l}\mathrm{L} \\
\mathrm{G} \\
\mathrm{A}\end{array}$ & Total & AGA & $\begin{array}{l}\text { IU } \\
\text { GR }\end{array}$ & $\begin{array}{l}\mathrm{L} \\
\mathrm{G} \\
\mathrm{A}\end{array}$ & Total & $\begin{array}{l}\mathrm{A} \\
\mathrm{G} \\
\mathrm{A}\end{array}$ & $\begin{array}{l}\mathrm{IU} \\
\mathrm{G} \\
\mathrm{R}\end{array}$ & $\begin{array}{l}\mathrm{L} \\
\mathrm{G} \\
\mathrm{A}\end{array}$ & Total & $\begin{array}{l}\mathrm{A} \\
\mathrm{G} \\
\mathrm{A}\end{array}$ & $\begin{array}{c}\mathrm{IU} \\
\mathrm{G} \\
\mathrm{R}\end{array}$ & $\begin{array}{l}\mathrm{L} \\
\mathrm{G} \\
\mathrm{A}\end{array}$ \\
\hline Normal Cases (50) & 5 & 4 & 1 & 0 & 19 & 16 & 3 & 0 & 21 & 16 & 4 & 1 & 5 & 4 & 1 & 0 \\
\hline $\begin{array}{l}\text { High Risk Cases (100) } \\
\text { PIH }\end{array}$ & 9 & 8 & 1 & 0 & 25 & 21 & 4 & 0 & 31 & 20 & 10 & 1 & 35 & 22 & 12 & 1 \\
\hline $\operatorname{SCA}(20)$ & 3 & 3 & 0 & 0 & 6 & 5 & 1 & 0 & 12 & 8 & 4 & 0 & 14 & 9 & 5 & 0 \\
\hline Postdated (15) & 0 & 0 & 0 & 0 & 6 & 6 & 0 & 0 & 6 & 4 & 1 & 1 & 8 & 8 & 0 & 0 \\
\hline & 0 & 0 & 0 & 0 & 3 & 3 & 0 & 0 & 6 & 2 & 0 & 0 & 6 & 5 & 0 & 1 \\
\hline APH (6) & 0 & 0 & 0 & 0 & 3 & 0 & 3 & 0 & 5 & 0 & 5 & 0 & 7 & 0 & 7 & 0 \\
\hline $\mathrm{Rh}-\mathrm{ve}(6)$ & 3 & 2 & 1 & 0 & 3 & 3 & 0 & 0 & 0 & 0 & 0 & 0 & 0 & 0 & 0 & 0 \\
\hline Diabetes (3) & 1 & 1 & 0 & 0 & 3 & 3 & 0 & 0 & 2 & 2 & 0 & 0 & 0 & 0 & 0 & 0 \\
\hline & 2 & 2 & 0 & 0 & 1 & 1 & 0 & 0 & 0 & 0 & 0 & 0 & 0 & 0 & 0 & 0 \\
\hline
\end{tabular}

In the present study in $50 \%$ cases a score lower than 7 is observed. On the whole a higher score is observed in high placental maturation. Agrawal V et $\mathrm{al}^{5}$ showed that a good Apgar Score is associated with higher grade placenta. Low birth weight baby $(<2.5 \mathrm{~kg})$ is observed in $50.25 \%$ of cases of grade III placenta. Lower gestational age shows lesser degree of placental changes. But when Grade III placenta develops prior to 35 weeks the IUGR develops. Kazzi et $\mathrm{al}^{9}$ showed that presence of Grade III placenta is related to 59\% of small for gestational age infant. Hills Irwin et al showed that in addition to placental grade other specific disease entity is also associated with low foetal growth. The respiratory distress syndrome is seen to be associated with grade 0 and grade I placenta and no cases were seen in grade II or grade III placenta. Similar findings were also shown by Shah YG et $\mathrm{al}^{10}$.

In the present study in $33.3 \%$ of grade 0 placenta and $28.5 \%$ of cases grade III placenta is seen to be associated with peri-natal morbidity. Quinlan et $\mathrm{al}^{11}$ reported a high incidence $78 \%$ of peri-natal morbidity associated with grade III placenta. Perinatal mortality was seen to be high in grade 0 


\section{JMSCR Vol||05||Issue||04||Page 20516-20521||April}

placenta due to inadequate lung maturity and in grade III placenta due to placental insufficiency. Quinlan et al $^{11}$ reported that grade III placenta is associated with adverse peri-natal outcomes. Agrawal $\mathrm{V}$ et $\mathrm{al}^{5}$ reported that earlier knowledge of placental grade can decrease the risk of peri-natal death by appropriate intervention.

Table. No 5 Correlation of placental grading and birth weight.

\begin{tabular}{|c|c|c|c|c|c|}
\hline Grade & $\begin{array}{c}\text { Total } \\
\text { cases }\end{array}$ & \multicolumn{4}{|c|}{ Birth weight in Kg } \\
\hline & & $\begin{array}{c}1-1.5 \\
\mathrm{~kg}\end{array}$ & $1.5-2 \mathrm{~kg}$ & $2-2.5 \mathrm{~kg}$ & $>2.5 \mathrm{~kg}$ \\
\hline Grade 0 & 14 & 4 & 3 & 3 & 4 \\
Grade I & 44 & 3 & 3 & 10 & 28 \\
Grade II & 52 & 2 & 6 & 6 & 38 \\
Grade III & 40 & 7 & 8 & 6 & 19 \\
\hline
\end{tabular}

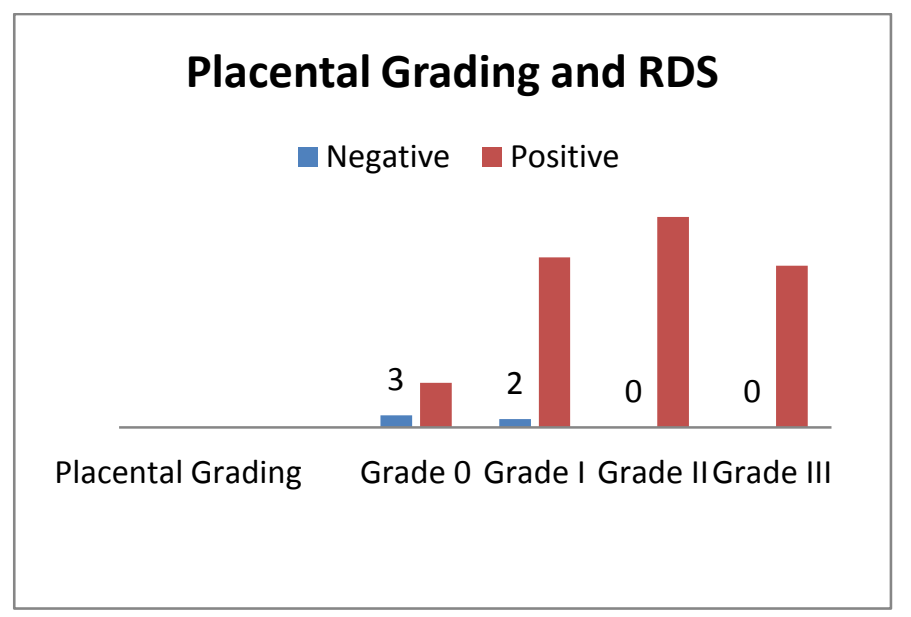

Fig. 1 Correlation of placental grading with respiratory distress syndrome

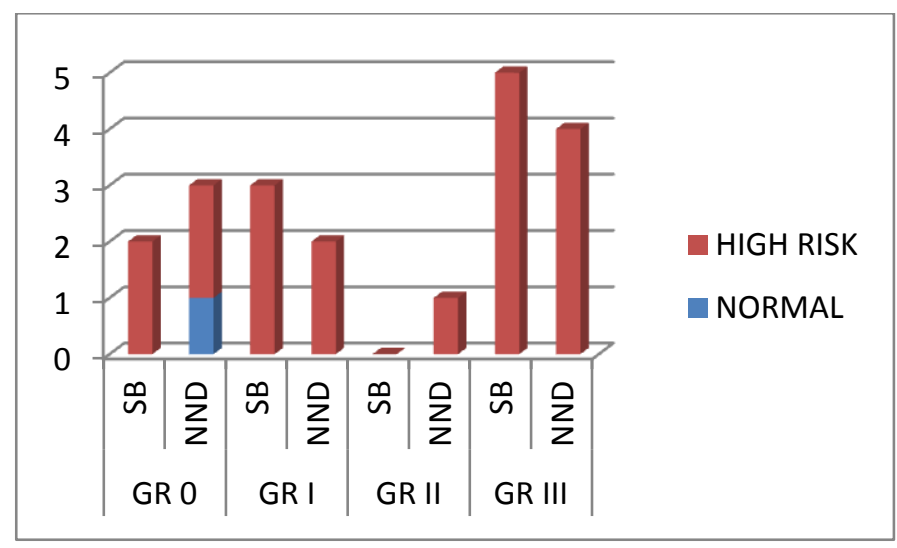

Fig. 2 Correlation of placental grading with perinatal mortality

\section{Conclusion}

From our study it is concluded that as the pregnancy advances the grade II and III placental changes becomes common. Placental grading is good predictor in the detection of IUGR or pulmonary maturity in cases of high risk pregnancies. Detection of higher grades of placenta early in $3^{\text {rd }}$ trimester can alert the obstetrician for close observation regarding development of PIH, IUGR, foetal distress and foetal maturity as there is definite correlation of early maturation of placenta with foetal complications.

No source of support or grant declared.

No conflict of interest declared.

\section{Abbreviations}

PIH- Pregnancy induced hypertension APH - Ante-partum haemorrhage

IUGR - Intra uterine growth retardation SB - Still Birth

NND - Neonatal Death

AGA - Appropriate for gestational age

SGA - Small for gestational age

LGA - Large for gestational age

\section{References}

1. Petrucha RA, Golde SH, Platt LD. Real time ultrasound of the placenta in assessment of foetal pulmonary maturity. Am J Obstet Gynecol. 1982; 142(4): 463-467.

2. Breckle R, Mark W, Wolfgram, et.al. Grade III placentation and neonatal outcome. Obstetric and Gynaecology; 1983, 61: 728732.

3. Kazzi GM, Gross TL,Sokol RJ et al. Detection of intra uterine growth retardation: a new use of sonographic placental grading. Am J Obstet Gynecol. 1983; 145(6): 733737

4. Hill LM, Breckle R, Ragozzino MW et al. Grade 3 placentation: incidence and neonatal outcome. Obstet Gynecol. 1983; 61(6): 728732.

5. Agrawal V, Jain S. Placental grading and its correlation with foetal outcome. Journal of obstetrics and Gynaecology India 2000;50:1, 59-62. 
6. Grannum PA, Berkowitz RL, Hobbins JC. The ultrasonic changes in the maturing placenta and their relation to foetal pulmonic maturity Am J Obstet Gynaecol. 1979; 133(8): 15-922.

7. Clair MR Rosenberg E, Tempkin D et al. Placental grading in the complicated or high risk pregnancy. J Ultrasound Med, 1983; 2(7): 297-301.

8. Arias F. Practical guide to high risk pregnancy and delivery. 2008 Elsevier India $3^{\text {rd }}$ Edn 278-279.

9. Kazzi GM, Gross TL, Rosen MG et al. The relationship of placental grade, foetal lung maturity and neonatal out come in normal and complicated pregnancies. Am J Obstet Gynecol. 1984; 148(1): 54-58.

10. Shah YG, Graham D. Relationship of placental grade to foetal pulmonary maturity and respiratory distress syndrome. Am J Perinatol. 1986; 3(1): 53-55.

11. Quinlan RW, Cruz AC, Buhi WC et al. Changes in placental ultrasonic appearance. Incidence of grade III changes in the placenta in correlation to foetal pulmonary maturity. Am J Obstet Gynaecol. 1982; 144(4): 468-473. 